\title{
THE GLACIAL DRIFTS OF THE LEINSTER MOUNTAINS
}

\author{
By A. Farrington, D.Sc. (Royal Irish Academy, Dublin) \\ (Paper read at a Meeting of the Society on 18 March 1948)
}

\begin{abstract}
Anstract. Five glacial phases are recognized in the area described. Two of these are represented by the deposits of ice-sheets from the north-east and north-west respectively; the other three were of local origin. The materials composing the drifts differ sufficiently to enable the stratigraphy to be seen clearly. This shows that the local ice caps alternated with the invading ice sheets - which brings out a point of considerable climatological interest in that it is clear that the local ice advanced not simultaneously with the invading ice sheets but alternated with them. The order in which the five phases occurred is well established, but the importance of the intervals between the phases is at present uncertain.
\end{abstract}

Zusammenfassung. In der beschriebenen Zone sind fünf Phasen zu erkennen. Zwei dieser Phasen sind auf Ablagerungen von Eisfeldern vom Nordosten und Nordwesten zurückzuführen, die anderen drei sind lokalen Ursprungs. Das Geschiebe ist verschieden genug aufgebaut, um die Schichtung deutlich erkennen zu lassen. Dies zeigt, dass die lokalen Eisdecken mit den eindringenden Eisfeldern abwechseln. Hierdurch wird ein Punkt von beträchtlichem klimatologischen Interesse hervorgebracht, insofern als es klar ist, dass die lokale Eisschicht nicht gleichzeitig mit den eindringenden Eisfeldern vorrückte sondern mit ihnen abwechselte. Die Aufbaufolge der fünf Phasen ist deutlich festgelegt, aber die Bedeutung der Zeitspanne von Phase zu Phase ist im Augenblick ungewiss.

No area hitherto examined in Ireland has proved so well fitted as the northern end of the Leinster Mountains to supply evidence to form the basis of a study of the chronology of the Irish glaciations. In this locality five glacial phases may be recognized. Two of these are represented by deposits of general ice sheets, one coming from the north-east and the other from the north-west, both of them thrusting high on to the flanks of the mountains. In the other three phases local ice caps formed on the mountains.

The following are the recognized glaciations, the most recent being placed first:

\section{Athdown Mountain Glaciation \\ Midland General Glaciation \\ Brittas Mountain Glaciation \\ Eastern General Glaclation \\ EnNiskerry Mountain Glactation}

The deposits of the general ice sheets contain characteristically large quantities of carboniferous limestone; the main content of the deposits of the local ice is granite and schist derived from the Leinster Mountains; accordingly, a good contrast may be seen where the deposits are superimposed.

Little is known of the lowest deposit, which is of local origin. Near Enniskerry it occurs as a purely granitic boulder clay underlying some of the later drifts. Elsewhere granite erratics found outside the granite area would seem to be best explained as having been distributed by an early local ice cap.

The next deposit is one which was brought up on to the mountain slopes by a general ice sheet coming from the north-east. This is characteristically a very tough till, usually of a dark chocolate colour and without many stones; a high proportion of those which do occur are well rounded and much striated limestone. This is the most usual manifestation of the deposit, but it varies from an almost stoneless black clay to a fairly stony reddish-brown clay. It is always calcareous and the sandy residue of washings is composed chiefly of well-rounded quartz grains. The till contains marine shells, whole and fragmentary. The glaciation that deposited this clay has been called the EASTERN GENERAL Glaciation because its boulder clay is particularly well developed all down the east coast of Ireland. The evidence of striae, and of the stone content, indicates that the ice which deposited it came from the north-east. It contains Cretaceous flints and other far-travelled rocks, some of which are not of Irish origin. It is an important deposit for the chronology of the 
Irish glaciations because it occurs along such a great length of the coastline, at least from Co. Louth to Co. Wexford, and is easily recognizable. It underlies a variety of different drifts and so gives a basis for the correlation of these, a task which has not yet been seriously attempted. It has been recognized as far inland as Saggart Hill, some ${ }_{5}$ miles $(24 \mathrm{~km}$.) from the coast; but there can be no doubt that the ice sheet extended much further west, as, at Saggart Hill, the deposits lie at up to $1000 \mathrm{ft}$. $(300 \mathrm{~m}$.) above sea-level. Many records exist of finds of marine shells from sites in the central lowland.

Overlying this clay in Co. Wicklow are gravels with a high content of granite pebbles. Near Enniskerry these gravels form a considerable delta, laid down by water flowing from the mountains, in which sections exposing a depth of over $100 \mathrm{ft}$. $(30 \mathrm{~m}$.) can be seen. A connexion may be traced

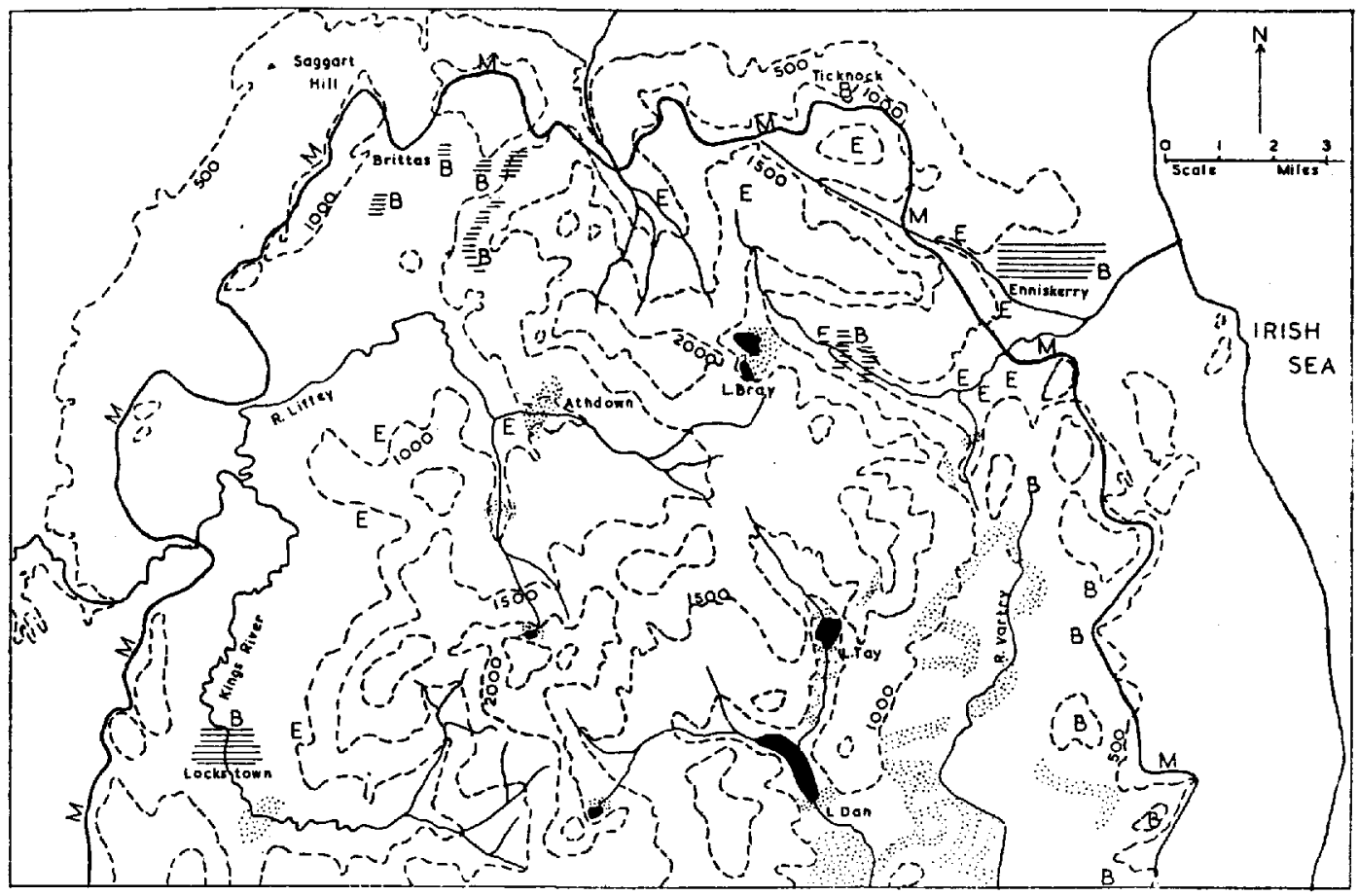

MAP OF THE NORTHERN END OF THE LEINSTER MOUNTAINS

Eastern General Glaciation

Brittas Mountain Glaciation

Midland General Glaciation

Athdown Mountain Glaciation
$E E E \ldots$

$B B B \ldots$ and horizontal ruling

$M M M$ standing on heavy line

Stippled areas

between this delta and beds of gravel seen in the sides of the valley of the Enniskerry river. These beds of gravel lie upon the lower boulder clay just described, and are covered by an upper limestone boulder clay.

Near Brittas, on the western side of the Dublin Mountains, gravels of the same composition and in the same stratigraphical position represent the marginal gravels of a local ice cap.

The limits of this ice cap, the Brittas Mountain Glagiation, are not known, except at the northern end of the Leinster Mountains; on the eastern and western flanks of the mountains its deposits are covered by the limestone drift of the later general glaciation. The position of the edge 
is determined in the Upper Liffey basin by the gravels near Brittas already mentioned and by a marginal moraine on a nearby hill slope.

The deposits of this local glaciation consist largely of granite gravel. Except in the heart of the mountains where the Eastern General Glaciation did not penetrate, they contain a varying proportion of non-local rocks (chiefly limestone, sandstone and chert) derived from that earlier invading ice sheet.

Near Brittas and Enniskerry the gravels of this mountain glaciation are covered in many places by fresh deposits of limestone-bearing morainic drift. This is the drift that has been classed as the Newer Drift. As this general term has been used for a variety of drifts which have not been proved to be contemporaneous, and as glacial deposits newer than the Newer Drift are known from many places in Ireland, it is proposed to discard it. The moraines and eskers of the central lowland of Ireland belong to this glaciation, now called the Midland General Glaciation.

Round the slopes of the Leinster Chain the drift of this glaciation occurs as morainic gravel and boulder clay. Outwash gravels fill much of the upper Liffey valley where they were dumped at the margin and later spread over the floor of a large glacial lake. In all types of this drift the limestone is fresh, even in exposures well within the granite boundary where the drainage from the mountains is acid. This is in strong contrast to the drift of the Eastern General Glaciation, which is completely leached, except where it occurs as a tough impervious till. The matrix of the Midland General boulder clay is more sandy and the colour lighter than that of unweathered boulder clay of the Eastern General Glaciation.

All the evidence available shows that this ice sheet came to Leinster from the north-west. However, since in this area it has overridden the earlier north-east drift of the Eastern General Glaciation, its deposits may contain, as derivatives, far-travelled erratics and marine shells. It is obvious that any ice coming from the north-west could have little other opportunity to pick up marine shells, and no other opportunity at all of incorporating north Irish or Scottish rocks.

The limits of the drift of the Midland General Glaciation on the mountain slopes are fairly clearly marked. The ice sheet rounded the northern end of the Leinster Mountains at I200-I $300 \mathrm{ft}$. $\left(3^{6} 5-396 \mathrm{~m}\right.$.) above sea-level. It moved down the eastern side, the level of the margin falling steadily, until it passed out to sea a little north of Arklow, returning again to the coast under some unknown influence to form the magnificent moraines near Blackwater, Co. Wexford. On the western side of the chain a similar but gentler fall of the level of the ice front may be traced on the hills.

A local glaciation which occupied the mountain valleys and spread over the Vartry plateau represents the last glacial phase that has been recorded. The deposits of this glaciation are valley moraines and outwash gravels. Every valley of the main mass of the Leinster Mountains contains moraines and in the upper valley of the King's River the outwash gravels are extensive. They form a long train as far as the junction with the river Liffey 7 miles from the outermost moraine. The drift contains only the local granite and schist, except where some of the earlier drift has been incorporated in the outwash gravel. This local glaciation has been termed the ATHDown MounTaIN Glaciation after the location of its extreme moraine in the upper valley of the river Liffey.

The stratigraphy of these different deposits gives a clear story of the order in which the various glaciations occurred, but it is difficult to assess the importance of the intervals between them. In the Wicklow mountain area the Athdown glaciation is shown to be later than the Midland General Glaciation by the relation of the drainage of the local glaciation to the drifts of the general glaciation. Not far outside the area occupied by the Athdown ice is the late-glacial site at Ballybetagh. Here the bottom deposit is the unweathered boulder clay of the Midland General Glaciation covered by a layer of downwashed clay also unweathered (Zone I). This is separated by a bed of sub-arctic mud (Zone II) from the late-glacial solifluction layer (Zone III). Zone III is accepted as being contemporaneous with the Athdown glaciation. 
Here is a definite climatic break giving a recognizable succession which affords an opportunity of correlating the Wicklow area with sites over much of Ireland, as Zone II and III are now known in many other places.

Where the deposits of the Midland General Glaciation are superimposed on those of the Brittas Glaciation no weathered surface of the Brittas drift has been seen. However, in the areas that have not been reached by the ice of the Midland General Glaciation or that of the Athdown Mountain Glaciation, the deposits of the Brittas Mountain Glaciation are much eroded and weathered. This contrast is particularly well seen in south Co. Wicklow.

This is the only criterion available at present and it suggests a longer interval between the Brittas Mountain Glaciation and the Midland General Glaciation than between the latter and the Athdown Mountain Glaciation. The freshness of the topography of the two last mentioned is reasonably comparable and is in contrast with the subdued topography of the older glaciations.

The junction between the granite drift of the Brittas Mountain Glaciation and the underlying calcareous drift of the Eastern General Glaciation is seen both at Enniskerry and at Brittas. In the latter place the granite gravel of the moraine lies on an eroded and weathered surface of limestone boulder clay; at Enniskerry the granite gravel in the delta, wherever it has been observed, lies on a level surface of boulder clay which is only slightly weathered. The evidence is conflicting. However, the top of the Enniskerry delta of Brittas age has a level of about $380 \mathrm{ft}$. (I $16 \mathrm{~m}$.) above sealevel. It is difficult, however, to see how water could have stood at this level in this situation unless ponded by ice. The evidence of the glacial drainage channels favours the point of view that this ponding was caused during the retreat of the ice of the Eastern General Glaciation rather than during the advance of that of the Midland General Glaciation. Such an interpretation would imply that the Brittas Mountain Glaciation was practically contemporaneous with the Eastern General Glaciation-an expansion of the local mountain glaciation during the retreat of the main ice sheet. More evidence is needed on this point, which is important for future study, as it may be that the Brittas Mountain Glaciation has an equivalent in a very extensive local ice sheet in south-eastern Ireland.

The glacial succession as worked out in Co. Wicklow will help in correlating the drifts in other parts of Ireland. The deposits of the two general glaciations may be recognized for many miles along the coasts of Co. Wicklow and Co. Wexford. The two later mountain glaciations occur in other isolated mountain groups, and the study of the relations of these local drifts to those of the general glaciations should make it possible to decide whether the lower boulder clay of the west of Ireland is of the same age as the lower boulder clay of the east. This will be a first step towards determining the periods of the very remarkable glaciations of Cork and Kerry which cannot at present be correlated with the other Irish deposits.

\section{R E F E R E N C E S}

The preceding account of the glacial chronology of the Wicklow mountains has been prepared in great part from material published in the papers listed below. It also contains material from unpublished observations made by the author. Charlesworth, J. K. The glacial retreat from Central and Southern Ireland. Quarterly fournal Geological Society, Vol. 84, I 928 , p. 293-342.

Fartington, A. The glaciation of the Wicklow Mountains. Proceedings Royal Irish Academy, Vol. 42, B, I934, p. I73-209.

Farrington, A. The local glaciers of Mount Leinster and Blackstairs Mountain. Proceedings Royal Irish Academy, Vol. 45, B, 1938 , p. 65 .

Farrington, A. The granite drift near Brittas, on the border between Co. Dublin and Co. Wicklow. Proceedings Royal Irish Academy, Vol. 47, B, r942, p. 279-9r.

Farrington, A. The glacial drifts of the district around Enniskerry, Co. Wicklow. Proceedings Royal Irish Academy, Vol. 50, $B, 1944$, p. $133-57$.

Farrington, A. Notes on the glacial geology of the Glen of Aherlow. Bulletin Geographical Society Ireland, Vol. r, 1945, p. $42-45$.

Jessen, $\mathrm{K}$. and Farrington, A. The bogs of Ballybetagh near Dublin, with remarks on late-glacial conditions in Ireland. Proceedings Royal Irish Academy, Vol. 44, B, 1938, p. 205-60. 


\section{I S C USS I O N}

The Chairman (Professor S. E. Hollingworth, University College, London): We have listened with great interest to Dr. Farrington's paper. Ireland is one of the few places in the British Isles where it has been possible to study the advances and recession of the ice from local mountain centres in relation to those of the larger ice sheets due to regional glacierization. It would seem that in Britain the only hope would be that Snowdonia might have provided somewhat analogous conditions to those of the Leinster Mountains. The confluence of ice masses, however, may have been dominant during the major advances of the ice. Professor Austin Miller knows the eastern side of Ireland well and perhaps he would like to say a word.

Professor A. Austin Miller (The University, Reading) : I had not intended to join in any discussion as my work is of a different type. I would however like to ask Dr. Farrington what is the form and altitude of the pre-glacial surface on which the glacial deposits rest, especially in the lowland areas under the drifts left by the regional glaciations?

Dr. FarRINGton: Records from wells and other excavations indicate that the sub-glacial surface of the central lowland of Ireland is a peneplane with a slight westward slope. On the east the level is about $220-240 \mathrm{ft}$. ( $70 \mathrm{~m}$.) above sea-level. There is some evidence of deep valleys crossing this surface but there are not sufficient data available for mapping.

The Chairman: We are very glad to welcome Dr. Münster Strøm here to-day. Perhaps he would like to contribute?

Dr. K. MÜNSTER STRøM (Oslo University) : I would like to ask Dr. Farrington whether it would ultimately be possible to make correlations across the Irish Sea, Britain and the North Sea to the Scandinavian area, especially to correlate the older glaciations. I would also be interested to know whether the wonderful series of lateral drainage channels and other glaciofluvial erosional or depositional features have been made use of to ascertain the waning of the latest glaciers?

Dr. FARRINGTON: The correlation of the late-glacial series of Ireland with that of Scandiaavia is now generally admitted. Correlations of earlier deposits have much less foundation and even between Ireland and Britain none is really well established. The lateral drainage channels have been used to ascertain successive positions of the waning ice-front but much of this work is still unpublished.

Mr. W. H. WARD (Building Research Station, Watford): Is it possible that some of the interglacial phases are extensive solifluction deposits? It struck me that in some of the deposits the stones were so angular that they were products of frost action. The "moraine" with such distinct boundaries might have been deposited by rapid thaw as a "stone river" rather than by an ice mass.

Dr. Farrington: I am quite prepared to accept any explanation! The moraine referred to is on the slope of Mount Leinster. From its position on the hillside, running approximately parallel to the contours, it could not have been a "stone river," but this point was not clear in the slide.

Mr. WARD: The glacial deposit immediately overlying the wave-cut rock platform struck me as being a solifluction bed.

Dr. FARRINGTON: The rock surface is striated and the nearest hills are a good quarter of a mile away, so solifluction seems unlikely.

Mr. WARD : Solifluction deposits could also cause striations and flow a long way.

Dr. FarRington: The deposit contains rounded and striated blocks and far-travelled erratics which certainly are glacial, so that even if it be a solifluction deposit much of its content is derived from an earlier glaciation. 
The Chairman: Would Mrs. Tutin like to contribute?

Mrs. W. Turin (University College, Leicester): The succession of late-glacial deposits in Windermere corresponds with that which Dr. Farrington has described from Ballybetagh. If the Athdown Mountain Glaciation is correlated with Zone III (the solifluction layer at Ballybetagh), it can also be correlated with the mountain glaciation in the English Lake District, which, presumably, produced the laminated clays which represent Zone III in Windermere.

Dr. Farrington: In my opinion the correlation of the Athdown Mountain Glaciation with Zone III at Ballybetagh and with the same zone in Windermere, and therefore with the late mountain glaciation in the English Lake District, is correct.

Mrs. Tutin: I should like to ask Dr. Farrington whether he regards the Antrim Coast Readvance, which he correlates with the Athdown Mountain Glaciation, as contemporaneous with the Solway Re-advance. There is, I think, as yet insufficient evidence in the Lake District for determining the relation between the Solway Re-advance on the Cumberland coast and the local glaciation which produced the Zone III laminated clay in the Windermere basin.

Dr. FarRington: In the present state of our knowledge one may, as a working hypothesis, correlate the Antrim Re-advance with the Stranraer-Lammermuir front, and the Carlingford Re-advance with the Solway Reradvance. But there is much more work to be done on both sides of the North Channel before these correlations can be made with much confidence.*

The Chairman in response to a query addressed to him on this point said that he could not add much more to Dr. Farrington's remarks. Opinions as to correlation had varied from time to time. The essential need was for more facts. Dr. Farrington's work was particularly noteworthy in that he had made a detached factual study of a critical region without passing to the phase of generalization. The evidence for oscillatory alternations of advances of ice sheets and the local centres was of considerable climatological interest. He asked Mr. Gordon Manley if he had any suggestions or comments that he would like to put forward on this aspect of the author's results.

Mr. Gordon Manley (Cambridge University): Is the Athdown glaciation confined to the places shown by Dr. Farrington or has the field work in north-west Ireland not yet been done? Meteorologically it is highly improbable that there has not been at least a well-developed mountain glaciation in north-west Ireland, at the same time possibly extending to lower levels than in Leinster. I am fascinated by the meteorological problems presented by Dr. Farrington's work and believe that they may be elucidated, and I hope to find a meteorological basis for correlations across the Irish Sea.

Dr. FarRington: Dr. Charlesworth, to whom we owe most of our knowledge of the glaciation of the northern half of Ireland, says that the late-glacial corries of the Mourne Mountains may perhaps be correlated with the Antrim Coast Re-advance. He says that there was virtually no lateglacial corrie period in north-west Ireland. The late-glacial series is known from sites in the west of Ireland, so that it is likely that some of the corries there belong to the same phase.

The Chairman : It only remains for me to thank Dr. Farrington very much for his most interesting paper and also those who have contributed to what has been a most stimulating discussion.

- Dr. Farrington has recently sent this additional note: "Since this paper was written Mr. G. F. Mitchell has informed me that an examination he has recently made of the deposits above the boulder-clay of the Antrim Coastal Re-advance in a section in the Marquess brick-pit in Belfast, makes it unlikely that the correlation of the Re-advance with Zone III is correct. In this pit a peat covered by an upper sand rests on top of the Antrim Coastal Re-advance deposits. In Mr. Mitchell's opinion the peat belongs to Zone II and the upper sand (which yielded a leaf of Salix herbacea) to Zone III." 